\title{
ПЕДАГОГІЧНА I ПРОСВІТНИЦЬКА ДІЯЛЬНІСТЬ ПАНТЕЛЕЙМОНА КУЛІША: 3 НАГОДИ 200-РІЧЧЯ ВІД ДНЯ НАРОДЖЕННЯ
}

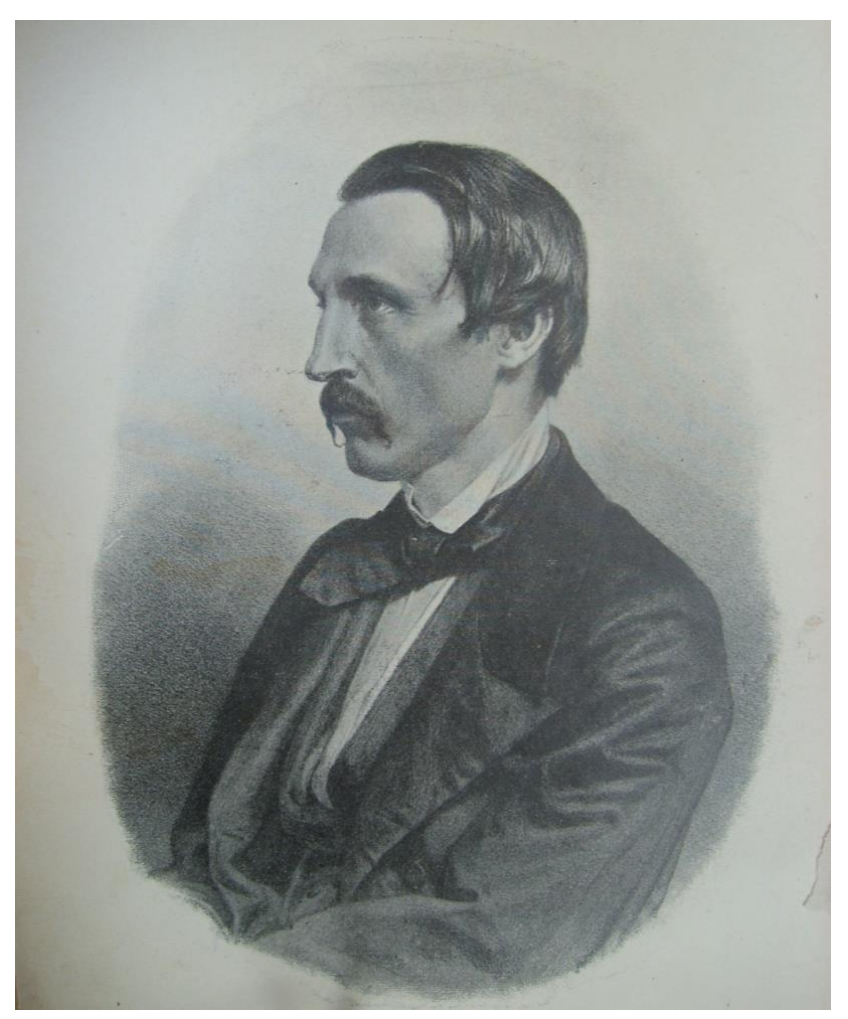

Постать Пантелеймона Куліша багатогранна. Він яскраво виявив себе як «визначний прозаїк, поет, драматург, перекладач, публіцист, критик, літературознавець, етнограф, фольклорист, мовознавець, педагог, історик, філософ, історіософ, культуролог, релігієзнавець, соціолог, політолог, художник, видавець, громадський діяч, організатор національної культури й просто - дбайливий український сільський господар та інтелігент європейського типу» [10, с. 7]. Довгий час його талант і творча спадщина не були належно поціновані, вивчені й популяризовані. Ще за життя вченого міцно вкоренився стереотип «суперечливого» стосовно його особистості та ідейних переконань. А за радянських часів П. Куліш одержав ярлик «українського буржуазного націоналістичного діяча», що й визначало методологічний інструментарій кулішезнавчих досліджень.

Модерна соціально-політична й ідеологічна ситуація, із притаманними їй ідейним плюралізмом, зверненням учених до цивілізаційних, культурологічних, соціокультурних підходів при дослідженні національної культурної спадщини зумовили переосмислення вітчизняного історико-культурного досвіду, в тому числі внеску окремих українських діячів. Сучасні вченікулішезнавці М. Бойко, В. Владимирова, П. Гончарук, Л. Грінберг, М. Жулинський, В. Івашків, К. Ісаєнко, С. Ковпік, Є. Нахлік, Л. Похила, А. Сініціна, В. Терлецький, О. Федорук, О. Шокало, Ж. Янковська та інші висвітлюють літературні, літературознавчі, літературно-критичні, етнографічні, історико-філософські здобутки П. Куліша, осмислюють епістолярну і мемуарну спадщину вченого, по-новому прочитують його особистість, вводять до наукового обігу першоджерела, архівні, інші маловідомі матеріали, тим самим повертаючи цінні надбання українській культурі.

Аналіз багатої історіографії творчості П. Куліша засвідчує, що не було приділено належної уваги його педагогічній і просвітницькій діяльності, а також залишалися поза увагою дослідників педагогічні погляди, ідеї.

Вперше педагогічного аспекту життєтворчості П. Куліша в 20-ті pp. ХХ ст. торкнувся М. Стороженко в статті «До біографії Куліша» (1923), уточнив послідовність його службових переміщень на посаді вчителя, а також опублікував рукописний журнал для розписки вчителів другого дворянського училища за 1841 р., де працював П. Куліш.

Неабиякий інтерес до вивчення педагогічної діяльності П. Куліша викликає стаття С. Дорош «Пантелеймон Куліш» у журналі «Biльна українська школа» (1919). Авторка статті описала педагогічні погляди вченого, дала високу оцінку його діяльності, спрямовану на підтримку освітянського руху. Особливу увагу приділено внеску П. Куліша у підготовку навчальної літератури для шкіл рідною мовою. С. Дорош наголосила на ролі просвітника в культурноосвітньому процесі другої половини XIX ст. та зазначала, що «П. Куліш повинен зайняти почесне місце в історії української педагогіки».

У праці «П. О. Куліш педагогом» (1927) I. Ткаченко дав загальний начерк педагогічної роботи просвітника, його внеску в освітній роз- 
виток українського народу, що ним став перший рідномовний підручник «Граматка», а також проаналізував його педагогічні статті в «Основі» та «Правді». До історії створення «Граматки», їі розповсюдження, заборони, успіху серед простого населення, звернувся В. Міяковський у розвідці «3 просвітньої діяльності П. А. Куліша» (1919).

Радянський період характеризується вивченням педагогічно-просвітницької діяльності П. Куліша на засадах марксистської ідеології. Як зауважив Н. Гупан, такий критерій «...добору історико-педагогічного матеріалу призводив до прямого викривлення ідей видатних педагогів минулого, до зведення загальної картини історико-педагогічного процесу в більшовицьку схему» [4]. Високоідейні національні погляди П. Куліша штучно замовчувалися, ім'я викреслювалося 3 історії української культури, зокрема освіти, а якщо часом дещо і мовилося, то упереджено, хибно. Пояснення такого підходу вчених до висвітлення педагогічної спадшини П. Куліша та інших педагогів цього періоду дає О. Сухомлинська: «Загалом, історіографічний аналіз публікацій про педагогічні персоналії, що бере свій початок із середини ХІХ ст. свідчить, що вибір персоналій, висвітлення біографічних фактів життя, змісту і напрямів їх творчості завжди залежали від політичного й ідеологічного впливу. Бували роки, коли історик педагогіки повністю й беззастережно віддавався політиці на шкоду педагогіці» [17].

У статті «Освітньо-педагогічна спадщина (До 170-річчя 3 дня народження П. Куліша)» (1989) М. Веркалець відзначав вагомий внесок педагога у видання навчальної літератури, показав його палким патріотом своєї нації, окремо наголосив на значенні «Граматки» П. Куліша в освітньому відродженні українського народу.

Окремі аспекти просвітницької і педагогічної діяльності П. Куліша, зокрема активна участь у Петербурзькій Громаді, авторство першого україномовного підручника, співпраця із першим загальноукраїнським журналом «Основа» згадуються у дослідженнях сучасних вченихдослідників української історії педагогіки О. Сухомлинської, Л. Березівської, Н. Гупана, І. Зайченка, Л. Пироженко, Н. Побірченко. Так, безпосередня участь П. Куліша у просвітницько-педагогічному русі проаналізована у дослідженні Н. Побірченко «Педагогічна і просвітницька діяльність українських Громад у контексті суспільного руху Наддніпрянської України (друга половина XIX - початок XX століття)» (2001). Авторка фундаментальної праці подає біографічні моменти життя педагога, спрямованість його просвітницької роботи у складі Петербурзької громади, вказує на роль П. Куліша у створенні навчальної літератури рідною мовою.
Інтерес до особистості П. Куліша як педагога активізувався останнім часом. Свідченням цього факту є перше перевидання його педагогічних праць «Викохування дітей» $\mathrm{i}$ «Перегляд українських книжок», що ввійшли до спільного видання німецько-українського проекту - хрестоматії «Маловідомі першоджерела української педагогіки (друга половина XIX - XX ст.)» (2003) за науковою редакцією О. Сухомлинської.

До навчального посібника Академії педагогічних наук України «Українська педагогіка в персоналіях» (2006) за редакцією О. Сухомлинської увійшла стаття Н. Побірченко «Пантелеймон Куліш», що містить біографічні відомості, інформацію про педагогічний доробок вченого, його погляди на освіту й виховання. Це перша цілісна розвідка, в якій конструктивно оповідається про П. Куліша як педагога, його погляди на освіту.

Педагогічна діяльність Пантелеймона Олександровича Куліша представлена у статтях В. Терлецького «Педагогічні погляди П.О. Куліша», В. Лазарєвої «Українознавча спадщина П. Куліша в розбудові національної освіти», А. Кирпач «"Граматка" П. Куліша - один із перших україномовних підручників XIX ст.». Автори висвітлюють окремі аспекти педагогічної спадщини П. Куліша, а саме - роль «Граматки» в освітньому поступі українського народу в другій половині XIX ст., у розвитку національної освіти і виховання.

Актуальність дослідження педагогічної спадщини П. Куліша зумовлена об'єктивною потребою збагачення сучасних освітніх процесів ретельним вивченням, неупередженою оцінкою, творчим осмисленням 3 сучасних методологічних позицій кращих надбань української педагогічної думки. Його педагогічні погляди та ідеї стосовно становлення національної освіти $є$ суголосними нинішнім освітньо-виховним орієнтирам.

Зазначимо, що П. Куліш залишив нащадкам надзвичайно багату і важливу для розвитку освіти педагогічно-просвітницьку спадщину. Він $\epsilon$ автором науково-педагогічних статей «Какие руководства удобнее употреблять при первоначальном обучении крестьянских детей?», «Виховування дітей», «Викохування дітей за підмогою школи», «Устня мова 3 науки», «Перегляд українських книжок», «Простонародность в украинской словесности», в яких порушував питання національної освіти, що має нерозривно поєднуватися із корінням народу, його мовою, звичаями, історією, відповідати потребам народу і здатна виховувати національно свідоме покоління із сталим почуттям патріотизму, громадянською позицією, ціннісними орієнтаціями, духовністю.

Загально педагогічні погляди П. Куліша 
полягали в ідеї про необхідність реорганізації освітніх закладів відповідно до національних особливостей українського народу; побудови навчально-виховного процесу за принципами природовідповідності та народності; високого навчально-методичного рівня особистості вчителя; обов'язкової жіночої освіти; чіткої структурної послідовності освіти: дошкільне сімейне виховання, навчання в школі, вища освіта; використання у практиці вітчизняної школи зарубіжного досвіду з метою запозичення кращих освітніх надбань передових країн світу; тісного співробітництва сім'ї та школи; виховання дитини в колективі; використання у навчально-виховному процесі теоретично розроблених і науково обгрунтованих методів навчання.

Змагаючись за національну школу в Україні, дбаючи про оновлення змісту освіти, унормовуючи український правопис, П. Куліш у вкрай несприятливих умовах упорядкував і видав підручник для початкової школи «Граматка» двома виданнями $(1857,1861)$.

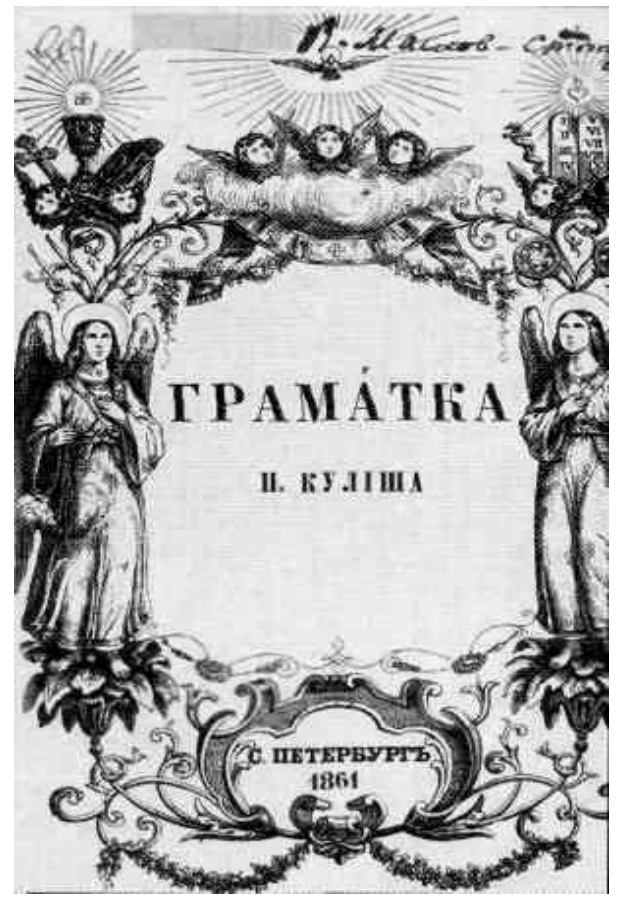

Загалом, у кінці 50-х - на початку 60-х рр. XIX ст. розпочинається «...досить-таки інтенсивний Петербурзький період українського друкованого слова. Найбільш енергійним діячем, можна сказати, - душею видавничої справи - як зазначив С. Єфремов, - став цим разом Куліш. Допіру він дістав змогу, по десятилітньому мовчанні, виступати в літературі вже під власним ім'ям і розгортає кипучу, як на одну людину, i - що найголовніше - систематичну вже до певної міри працю у сфері українського видавництва» [5].

У 1857 р. в Петербурзі П. Куліш заснував власну друкарню, яка мала назву «Друкарня
П. А. Куліша». Під час виїзду за кордон 1858 р. він за власні кошти придбав друкарську машину в Берліні. У спогадах сучасників згадується, що «типография была на Вознесенском проспекте со скоропечатною машиною, им впервые заведенною в России, и обставлена она была довольно роскошно» [14]. Вона стала першою і єдиною в XIX ст. українською друкарнею в підросійській Україні і «...тим самим зробила велику запомогу національному розвиткові того часу» [13].

Для П. Куліша вирішення проблеми видання україномовних книг стало окремим напрямом його науково-педагогічної діяльності. Він добре розумів, що єдиний засіб національного самоусвідомлення та поширення грамотності серед населення - це рідномовна книга, створена на національній основі. Вона найефективніша у морально-етичному плані та розвитку розумових здібностей учня. Створення підручників та книг українською мовою стало важливим завданням просвітника.

Ідея створення підручників у просвітницькій діяльності П. Куліша бере початок ще від його співпраці з членами Кирило-Мефодіївського товариства, котрі велику увагу приділяли справі народної освіти. У пункті 8-му «Правил» кириломефодіївців наголошувалося: «Товариство буде турбуватися заздалегідь про викорінення рабства і будь-яке приниження нижчих класів і про широке поширення грамотності» [6].

Теоретичне обгрунтування намірів друкувати книги і підручники простежується у зізнаннях П. Куліша під час процесу КирилоМефодіївських братчиків 1847 р. на допиті у III відділенні. На запитання жандармів «Какие книжки вы думали писать...?» він відверто виклав свою програму: «...ми мали намір написати короткі підручники українською мовою священної і громадянської історії, географії, обрахунку і сільського господарства...» [7]. Арешт і заслання у справі Кирило-Мефодіївського товариства, заборона права друку майже на десять років відсторонили П. Куліша від видавничої справи.

Друкування підручників для навчання грамоти П. Куліш продовжив після повернення iз заслання у 50-х pp. XIX с., коли завдяки лібералізації суспільного життя стало можливим реалізовувати свої ідеї у справі підручникотворення. В. Міяковський зазначав, що в цей час діяльність Петербурзької Громади, членом якої був П. Куліш, щодо видання книжок була продовженням намірів кирило-мефодіївців. А в період «...поміж цих двох дат - 1847-ий і 1860-ий рр. маємо в історії книжки майже порожнє місце, як наслідок терору, що спіткав був українську справу із суровим присудом 47-го року» [12].

«Граматка» була високо оцінена сучасни- 
ками педагога. Так, Т. Шевченко у своєму щоденнику записав: «Як прекрасно, розумно і благородно створений цей новий буквар. Дай Бог, щоб він привився у нашому бідному народі. Це перший вільний промінь світла, який зможе проникнути у подавлену попами невільничу голову» [19]. А. Лазаревський також вказав на важливість Кулішевої праці, враховуючи, що це перший досвід україномовного підручника: «Граматка складена дуже і дуже не дурно, і як перший досвід, заслуговує великої уваги...» [18]. В. Міяковський через десятки років після ï видання Куліша писав: «Дійсно, залюбки він складав свою Граматку, вклав в неї душу щирого й гарячого патріота...» [13].

Стосовно практичного успіху «Граматки» як україномовного підручника в журналі «Основа» А. Городинський наводить переконливі факти. В одній із полтавських шкіл, що нараховувала 157 учнів (із них - 23 росіяни), 114 наполягали на навчанні українською мовою. Школу відвідав член Комітету Грамотності О. Кониський. Він попросив найкращу ученицю прочитати щонебудь. Дівчина гарно й швидко прочитала, але на прохання переказати прочитане відповіла, що не може, бо не вчила напам'ять. Тоді їй дали «Граматку» Куліша і попросили прочитати про те саме, вона прочитала й переказала. В інших школах ситуація була подібна. Діти знали напам'ять священне писання, але не могли сказати, як звали матір Ісуса Христа і хто такий Iсус; не розуміли значення слів «плодъ», «туча», «агнець». Слід було лише перекласти ці слова українською мовою - і все ставало зрозуміло [15].

Ще одним підтвердженням високого рівня підручника є спогади Х.Д. Алчевської, у яких вона зазначала, що коли розпочала у 1862 р. свою педагогічну діяльність у жіночій недільній школі, то з власної ініціативи вперше навчала рідною мовою учениць і в цій справі використовувала «Граматку» П. Куліша, хоча на той час викладання в основному відбувалося російською мовою: «Час українського руху 60-х років збігся із захопленням інтелігенції недільними школами, i я пішла туди. У них вчили, звичайно, поросійському, і тільки моїй обширній групі учениць я роздала граматку Куліша і почала вчити їх по-українськи» [2].

Крізь призму сучасних дидактичних вимог до створення підручників для початкової школи «Граматку» П. Куліша визначаємо як підручник для початкового навчання, який відповідає таким критеріям: реалізація провідних дидактичних функцій (інформаційної, розвивальної, виховної); чітке структурування навчального матеріалу (наявність основного і додаткового текстів, різних видів навчальних завдань і вправ, ілюст- ративного матеріалу); відповідність його змісту дидактичним принципам (науковості, народності, доступності і свідомості засвоєння знань, наочності, зв' язку навчання з життям).

П. Куліш добре розумів, що кожен українець повинен знати історію предків, їх героїчні подвиги і поразки, усвідомлювати роль рідного народу в світовій історії. Народ, який не знає свого історичного минулого, на думку П. Куліша, не в змозі самореалізуватися як нація. Тому вивчення історії (науки пізнання й самопізнання) повинно стати загальнообов' язковим і повинно розпочинатися ще 3 юнацького віку, що сприятиме національній самоідентифікації. Його книга «Повесть об украинском народе, написал для детей старшого возраста П. Кулеш» (1846) була першим досвідом написання підручного видання для дітей із дидактичним опрацюванням історичних знань, з урахуванням вікових особливостей.

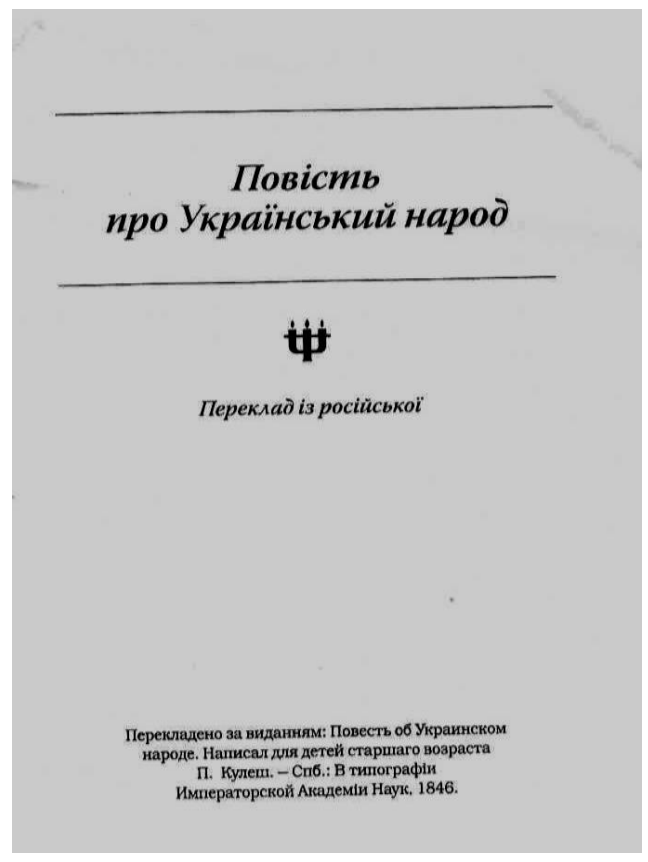

3 метою збереження етнографічної спадщини українського народу П. Куліш видав два томи «Записок о Южной Руси» (1856-1857), які становлять цілісний етнографічний матеріал, упорядкований новаторським, оригінальним на той час способом. Саме пам'ятки народної творчості містять у собі первинне історіософське бачення українського народу, його філософію, ментальність. Вони є духовно близькими для українця. Ще О. Кониський у праці «Наські граматки» радив усім упорядникам і видавцям українських підручників вміщувати у них твори 3 двотомника П. Куліша, як важливий виховний матеріал, спрямований на збереження історичних і культурних цінностей українського народу [11]. 


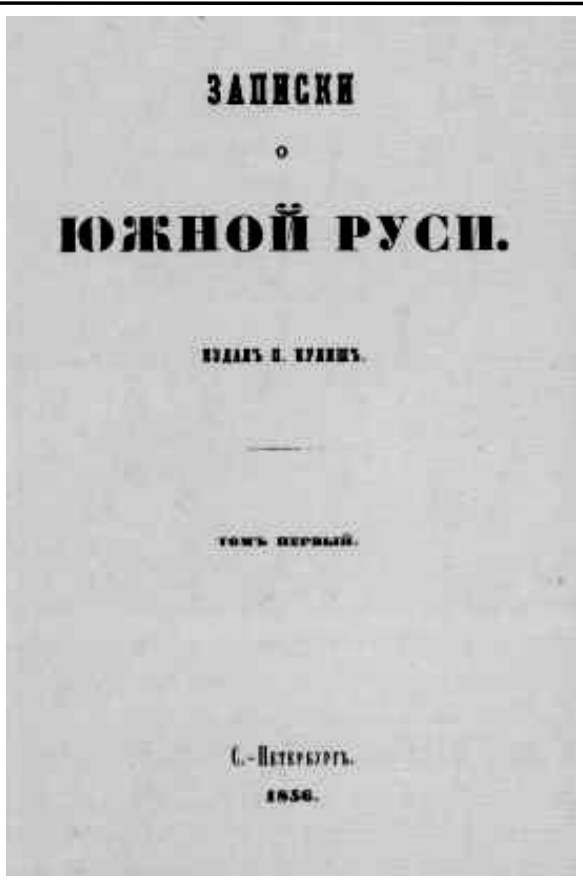

Сам П. Куліш розумів, що праця, яку він вклав у «Записки», - то велика справа. «Врятувати від забуття пам'ятки життя свого народу $є$ справжній подвиг, - писав він, - і тепер має велику важливість в очах кожної істинно освіченої людини» [8].

П. Куліш був редактором і видавцем збірок «Народні оповідання Марка Вовчка» (1857), «Повісті Квітки-Основ' яненка» (1857), а також надрукував історичний роман «Чорна рада», який зробив його відомим серед російської та української громадськості.

У 1860 р. Пантелеймон Куліш видав україномовний альманах «Хата», де поряд з власними творами вмістив поезії Т. Шевченка, Е. Гребінки, Я. Щоголева, Кузьменка, прозу Марка Вовчка та Ганни Барвінок.

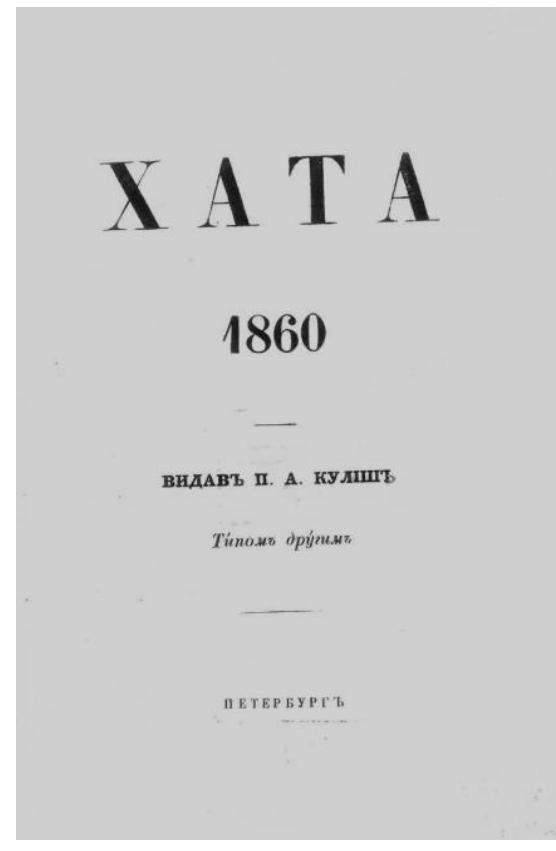

Постать П. Куліша нерозривно пов'язана 3 діяльністю першого загальноукраїнського журналу «Основа» (1861-1862), а також галицької «Правди», на шпальтах яких друкувалися його публікації педагогічно-просвітницького характеру, виступи на захист української мови як оригінальної і самобутньої. Він був ініціатором друкування творів українського письменства, публікацій критичних статей з української літератури, розвідок з історії України та етнографії.

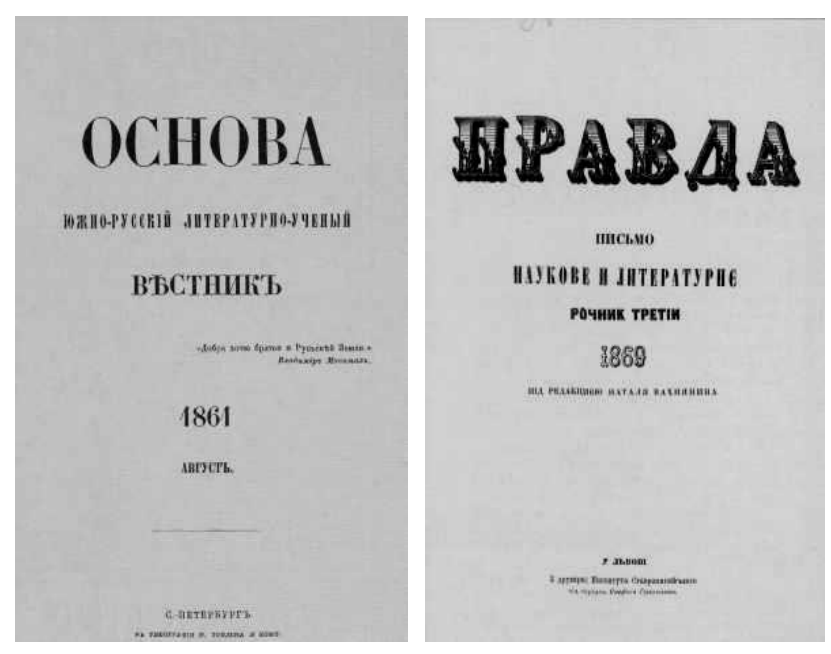

Для П. Куліша народна освіта була основною рушійною силою культурного розвитку та пробудження національної свідомості українців. Він підкреслював, що лише та освіта є життєдайною, яка відповідає характеру народного життя і його потребам. Водночас учений розумів, що грамотність ще не досить поширена серед люду, а навчальні заклади не багато дають користі. Тому важливим просвітнім і духовним засобом освіти є, на його думку, релігійні твори рідною для народу мовою, які здатні виховувати високі духовні якості людини. 3 цією метою П. Куліш переклав і видав «Проповіді на малоросійській мові, протоієрея Василя Грегулевича» (1857), які, як він вважав, спрямовані для моральних потреб.

Автор «Проповідей» акцентував на необхідності навчання кожної людини грамоти, на значенні освіти як для окремої особи, так і для всього суспільства. В. Грегулевич поширював думку, що особа повинна керуватися високими духовними якостями, працювати задля загальнолюдської користі, а не власних матеріальних інтересів. 3 цього приводу П. Куліш писав: «Хто вчитається в малоросійські проповіді, той переконається, що вони і по змісту, і по викладу можуть служити для рятівної потреби душі християнської; всякий, в якій би долі не знаходився, найде в них для себе і керівництво, і полегшення, і заспокоєння» [9].

Видання «Проповідей» украӥнською мовою, як був переконаний П. Куліш, «буде самий істотний і самий надійний крок вперед у справі усві- 
домлення нашої національної самостійності, до якої закликає нас давно вже пробуджена і нині доблесно підбадьорена самосвідомість народна» [9].

3 культурно-просвітнищькою метою П. Куліш протягом 1860-1862 рр. видав у своїй друкарні серію українських народних видань (так звані «метелики») під загальною назвою «Сільська бібліотека». 3 цього приводу С. Сфремов писав: «Надто цікава спроба Куліша видавати серію книжок спеціально для народного читання під спільною назвою “Сільська бібліотека” .. Це була перша спроба систематичного видавництва для народа..., а то й перша взагалі спроба цілком популярної книги, - спроба, що на довго й по тому визначила була у нас тип народної книжки, так званих "метеликів" » [16]. У ювілейному виданні, присвяченому 400-річчю книгодрукування в Роcii, йшлося: «Типографія Куліша зробила першу спробу друкування популярної книги українською мовою... “Сільська бібліотека” була одним із проявів звернення української інтелігенції до народу» [1].

Дійсно, це був перший досвід видання творів талановитих українських письменників окремими невеличкими брошурами для сільського народу з метою елементарної, але широкої народної освіти. «Эти книжечки, - писав Б. Грінченко, - прозванные среди публики "метеликами", представляли тогда почти единственный доступный для народа материал для чтения» [3].

Водночас, вивчення художньої спадщини П. Куліша дало можливість виявити ії освітньовиховні ідеї. У літературних, поетичних творах представлено погляди автора стосовно виховання дітей і молоді, які полягали у критиці існуючої станової школи, схоластики і догматизму в навчанні («Хутірська філософія і віддалена од світу поезія», 1879; «Маруся Богуславка», 1899); необхідності національної спрямованості освіти і виховання («Яков Яковлевич», 1852; «Остап Вересай. Сокиринський кобзар», 1868); пріоритетній ролі виховання в сім'ї як осередку духовності, моральності («Михайло Чарнишенко», 1843; «Майор», 1860); виховання дітей і молоді на засадах народної педагогіки («На почтовій дорозі в Малоросії», 1859; «Українські незабудки», 1861; «Старосвітське дворище», 1861).

Намагаючись донести до українського народу духовне багатство світової класичної літератури, він переклав українською мовою низку драматичних творів В. Шекспіра, творів Д. Байрона, Ф. Шіллера, ліричних поезій Г. Гете. У перекладі творів світових класиків рідною мовою П. Куліш убачав національне відродження шляхом залучення багатства світової літератури до національної культури. Колосальною його працею став переклад українською мовою «Біблії».

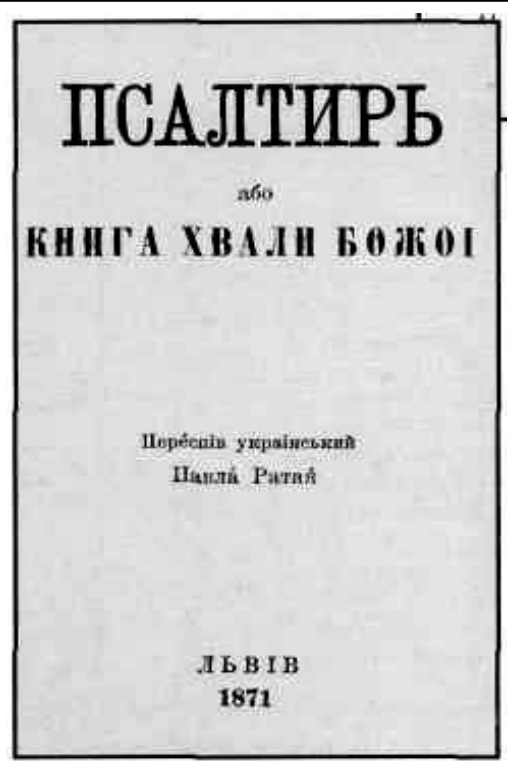

Це далеко не повний перелік його подвижницьких справ заради освітнього і культурного поступу українського народу. Вражає далекоглядність Генія і широкомасштабність його праць.

Таким чином, педагогічно-просвітницька діяльність П. Куліша є багатовимірною і спрямована на піднесення культурно-освітнього розвитку українського народу. У контексті складних суспільно-політичних перетворень вона $€$ взірцем міцної громадянської позиції, високих патріотичних почуттів, свідомого служіння національним інтересам і збагачення інтелектуального потенціалу українського народу.

\section{СПИСОК ВИКОРИСТАНИХ ДЖЕРЕЛ}

1. 400 лет русского книгопечатания: 1564-1964. T. I. Русское книгопечатание до 1917 года.

2. Алчевская Х. Д. Передуманное и пережитое: дневники, письма, воспоминания. Москва, 1912. 467 c.

3. Гринченко Б. П. А. Кулиш: биографический очерк. Чернигов: [б. в.], 1899. С. 13.

4. Гупан Н. М. Українська історіографія історії педагогіки. Київ: А.П.Н., 2002. 224 с.

5. Сфремов С. В тісних рамцях. Українська книжка в 1718-1916 рр. К. : [б.в.], 1926.

6. Сфремов С. Просвітні заходи КирилоМефодіївського братства. Світло. 1913. № 4. С. 4.

7. Кирпач А. «Граматка» П. Куліша - один із перших україномовних підручників XIX ст. Початкова школа. 1999. № 4. С. 59.

8. Кулиш П. Записки о Южной Руси. СПб.: [б. в.], 1856. Т. 1. 312 с.

9. Куліш П. Про проповеди на малороссийском языке, протоиерея Василия Грегулевича. Русская Беседа. 1857. Т. 3. С. 60-70.

10. Куліш Пантелеймон. Повість про український народ; Моє життя; Хутірська філософія і віддалена од світу поезія / [упоряд., передм., 
пер., прим. О.Шокало]. Київ: Ред. журн. «Український світ», 2005. 384 с.

11. Маковей О. Панько Олелькович Куліш: Огляд його діяльності. Літературно-науковий вісник. 1900. Кн. 3. С. 161-183.

12. Міяковський В. Видавничі плани КирилоМефодіївського товариства. Книгар. 19171920. С. 1895.

13. Міяковський В. 3 просвітньої діяльності П. А. Куліша. Літературно-науковий вісник. 1919. Т. 7 (Кн. 7-9). С. 93-107.

14. Нахлік Є. К. Пантелеймон Куліш: особистість, письменник, мислитель: у 2 т. / НАН України. Львівське відділення Інституту літератури ім. Т. Г. Шевченка. Сер. «Літературознавчі студії». Вип. 11/12; Міжнародний фонд Пантелеймона Куліша. Київ: Український письменник, 2007. - Т. 1: Життя Пантелеймона Куліша: наукова біографія. 2007. Вип. 11. С. 127.

15. Переписка с волынским губернатором о студенте Киевского университета Средзинском Г., обучавшим крестьянских детей с. Холоневичи Луцкого у. Волинской губернии по книгам на украинском языке (1862). Ф. 442, оп. 812, спр. 48, 8 арк.

16. Сфремов С. В тісних рамцях. Українська книжка в 1718-1916 рр. Київ: [б. в.], 1926.

17. Сухомлинська О. Історико-педагогічний процес: нові підходи до загальних проблем. Київ, А.П.Н., 2003. 68 с.

18. Украинская литературная летопись. Черниговскія Губернскія Ведомоти 1858. № 13. С. 102.

19. Щоденник Шевченка. Основа. 1861. № 5. С. 6-13.

\section{REFERENCES}

1. 400 let russkogo knigopechataniya: 1564-1964. (Vol. 1: Russkoe knigopechatanie do 1917 goda) [in Russian].

2. Alchevskaya, H. D. (1912). Peredumannoe i perezhitoe: dnevniki, pisma, vospominaniya. Moskva [in Russian].

3. Grinchenko, B. (1899). P. A. Kulish: biograficheskiy ocherk. Chernigov: [b. v.], 13 [in Russian].

4. Hupan, N. M. (2002). Ukrainska istoriohrafia istorii pedahohiky. Kyiv: "A.P.N" [in Ukrainian].

5. Yefremov, S. (1926). V tisnykh ramtsiakh. Ukrainska knyzhka v 1718-1916 rr. Kyiv: [b. v.] [in Ukrainian].
6. Yefremov, S. (1913). Prosvitni zahody KyryloMefodiivskoho bratstva. Svitlo, 4, 4 [in Ukrainian].

7. Kyrpach A. (1999). "Hramatka" P. Kulisha odyn $\mathrm{z}$ naipershykh ukrainomovnykh pidruchnykiv XIX st. Pochatkova shkola, 4, 59 [in Ukrainian].

8. Kulish, P. (1856). Zapiski o Yuzhnoy Rusi. (Vol. 1). SBb.: [b. v.] [in Russian].

9. Kulish, P. (1857). Pro propovedi na malorossiyskom yazyke, protoiereya Vasiliya Gregulevicha. Russkaya Beseda, Vol.3, 60-70 [in Russian].

10. Kulish Panteleimon. Povist pro ukrainskyi narod; Moie zhyttia; Hutirska filosofiia i viddalena vid svitu poeziia. O. Shokalo (Ed.). (2005). Kyiv: Red. zhurn. "Ukrainskyi svit" [in Ukrainian].

11. Makovei, O. (1900). Panko Olelkovych Kulish: Ohliad yoho diialnosti Literaturno-naukovyi visnyk, Kn. 3, 161-183 [in Ukrainian].

12. Miiakovskyi, V. (1917-1920). Vydavnychi plany Kyrylo-Mefodievskoho tovarystva. Knyhar, 1895. [in Ukrainian].

13. Miiakovskyi, V. (1919). Z prosvitnioi diialnosti P. A. Kulisha. Literaturno-naukovyi visnyk. Vol. 7 (Kn. 7-9), 93-107 [in Ukrainian].

14. Nahlik, Ye. K. (2007). Panteleimon Kulish: osobystist, pys'mennyk, myslytel. (Vol. 1-2. Vol. 1: Zhyttia Panteleimona Kulisha: naukova biohrafiia). Kyiv: Ukrainskyi pysmennyk, issue 11, 127 [in Ukrainian].

15. Perepiska s volynskim gubernatorom o student Kievskoho universiteta Sredzinskom G., obuchavshim krestyanskih detey s Holonevichi Lutskogo u Volinskoy gubernii po knigam na ukrainskom yazyke (1862). F. 442, op. 812, spr. 48, 8 ark. [in Russian].

16. Yefremov, S. (1926). V tisnykh ramtsiakh. Ukrainska knyzhka v 1718-1916 rr. Kyiv: [b. v.] [in Ukrainian].

17. Sukhomlynska, O. (2003). Istoryko-pedahohichnyi protses: novi pidkhody do zahalnykh problem. Kyiv, A.P.N. [in Ukrainian].

18. Ukrainskaya literaturnaya letopis'. (1858). Chernigovskiya Gubernskaya Vedomoti, 13, 102 [in Russian].

19. Shchodennyk Shevchenka. (1861). Osnova, 5, 6-13 [in Ukrainian]. 